\title{
PERANCANGAN SISTEM PENGUKUR DETAK JANTUNG MENGGUNAKAN ARDUINO DENGAN TAMPILAN PERSONAL COMPUTER
}

\author{
Muhajirin $^{1}$, Ashari $^{2}$, A. Fadhila Tenri Sanga ${ }^{3}$ \\ Teknik Informatika STMIK AKBA ${ }^{1,2,3}$ \\ E-mail : aji@akba.ac.id ${ }^{1}$, ashari@akba.ac.id², a.fadhilatenrisanga@gmail.com ${ }^{3}$
}

\begin{abstract}
ABSTRAK
Penelitian ini bertujuan untuk menghasilkan sebuah alat pengukur detak jantung manusia yang mampu memudahkan ahli medis ataupun masyarakat umum mengetahui kondisi kesehatan orang lain atau dirinya sendiri. Data ini diperoleh melalui penelitian lapangan, penelitian pustaka, dan wawancara. Dari hasil penelitian menunjukkan bahwa penggunaan alat arduino, pulse sensor dan aplikasi dengan tampilan personal computer sebagai pengukur detak jantung manusia memberikan manfaat pada ahli medis dan masyarakat umum dengan tingkat akurasi $92,36 \%$.
\end{abstract}

Kata Kunci:Alat Pengukur, Detak Jantung, Arduino, Sensor Max30100, Personal Computer.

\begin{abstract}
The aims of the study were to design and implement a measuring human hear rateed based on arduino by using Personal Computer as display media. The data were obtaind through observation, interview, and recording. The results of the study ndicated that the use of the arduino, pulse sensor and personal computer application as the measure of human heart rate provides the advantage for medical experts and common people with an accuracy of $92.36 \%$.
\end{abstract}

Keywords:The gauge, Heart Rate, Arduino, Sensor Max30100, Personal Computer.

\section{Pendahuluan}

Jantung adalah organ tubuh manusia yang berfungsi untuk memompa darah keseluruh tubuh manusia, di dalam darah tersebut terdapat makanan serta oksigen bagi semua sel dan jaringan. Ketika jantung tidak berfungsi normal, maka berbagai fungsi tubuh akan terganggu. Mengingat pentingnya fungsi dan peranan jantung maka informasi tentang kondisi kesehatan jantung sangat penting.

Sebuah studi terbaru yang diungkapkan oleh dr. Basuni Radi, Phd, FIHA, FasCC, Data WHO saat ini menunujukkan bahwa penyakit kardiovakular (salah satu penyakit jantung) merupakan penyebab kematian nomor satu secara global, yaitu $31 \%$ kematian. Oleh sebab itu diperlukan sebuah inovasi baru sebagai upaya untuk mengurangi jumlah kematian yang disebabkan oleh penyakit jantung Salah satu parameter untuk mengetahui kondisi kesehatan jantung manusia adalah mengetahui detak jantung beats per minute (BPM). Detak jantung manusia normal berkisar antara 60-100 denyut per menit. Alat yang biasa digunakan oleh profesi ahli medis untuk memeriksa detak jantung manusia adalah stetoskop. Akan tetapi stetoskop mempunyai kekurangan dalam penggunaan karena alat ini masih bergantung pada ahli medis dan penggunaan tanpa pengetahuan dan keahlian yang cukup dapat meningkatkan kemungkinan kesalahan yang diakibatkan faktor manusia. Selain itu suara yang dikeluarkan stetoskop yang terlalu keras dapat merusak telinga pendengar.

Perkembangan teknologi saat ini sangat pesat termasuk di bidang 
mikrokontroler, hal ini memungkinkan munculnya berbagai inovasi yang dapat membantu mengatasi permasalahan dalam kehidupan sehari-hari salah satunya adalah alat yang mampu mengukur detak jantung manusia. Oleh karena itu dibuat sistem pengukur detak jantung berbasis arduino dengan tampilan personal computer.sistem ini diharapkan dapat memberikan alternatif dari permasalahan dalam di bidang kesehatan khususnya untuk dokter dan masyarakat pada umumnya untuk mengetahui kondisi kesehatan jantung pasien atau dirinya sendiri .

\section{Studi Literatur}

2.1 Perancangan

Menurut Masmukti (2011:1-5)

Perancangan (design) secara umum dapat didefinisikan sebagai formulasi suatu rencana untuk memenuhi kebutuhan manusia. Sehingga secara sederhana perancangan dapat diartikan sebagai kegiatan pemetaan dari ruang fungsional (tidak kelihatan/imajiner) kepada ruang fisik (kelihatan dan dapat diraba/dirasa) untuk memenuhi tujuan-tujuan akhir perancang secara spesifik atau obyektif. Dalam prosesnya, perancangan adalah kegiatan yang biasanya berulang-ulang (iterative) Kegiatan perancangan umumnya dimulai dengan didapatkannya persepsi tentang kebutuhan masyarakat, kemudian dijabarkan dan disusun dengan spesifik, selanjutnya dicari ide dan penuangan kreasi. Ide dan kreasi kemudian di analisis dan diuji. Kalau hasilnya sudah memenuhi kemudian akan dibuat prototipe. Kalau prototipe sudah dipilih yang terbaik selanjutnya dilempar ke pasaran. Pasar akan memberikan tanggapan apakah kebutuhan telah terpenuhi.

\subsection{Pembuatan}

Pembuatan adalah kegiatan untuk menghasilkan sesuatu. Dalam proses pembuatan dijelaskan bagaimana proses bahan-bahan yang sudah disiapkan dibuat dan dirakit sedemikian rupa sesuai desain atau perancangan yang di buat.

2.3 Personal Computer

Personal Computer adalah seperangkat komputer yang digunakan oleh satu orang saja/pribadi. Biasanya komputer ini adanya dilingkungan rumah, kantor, toko, dan dimana saja karena harga PC sudah relatif terjangkau dan banyak macamnya. Fungsi utama dari PC adlaah untuk mengolah data input dan menghasilkan output berupa data/informasi sesuai dengan keinginan user (pengguna). Dalam pengolahan data yang dimulai dari memasukkan data (input) sampai akhirnya menghasilkan informasi, komputer memerlukan suatu sistem dari kesatuan elemen yang tidak bisa terpisahkan.

\subsection{Jari}

Menurut Sharifuddin (2011) dalam Handayani (2014:7), jari dalam bahasa Inggris adalah digit (finger atau toe) merupakan suatu bagian tubuh yang berada pada tangan dan kaki baik yang kiri maupun kanan.ada manusia normal jari berjumlah lima, ssebagaimana terlihat pada gambar 1

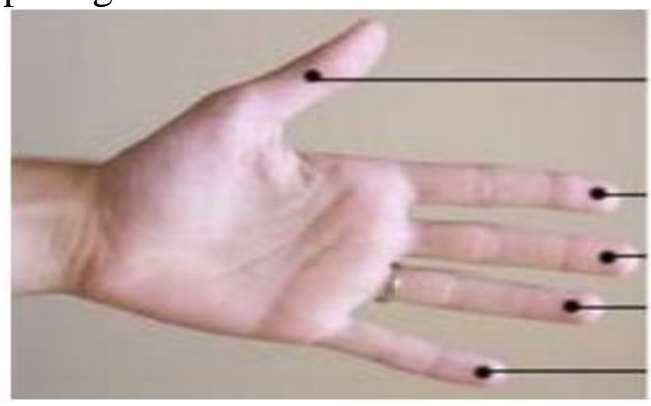

Gambar 1:Jari Tangan

(Sumber : Denyut Nadi

MelaluiPendeteksian Jari Tangan, 2014)

Jari terdiri dari beberapa ruas tulang yang diselimuti oleh daging atau otot, tidak hanya manusia saja yang memiliki jari, sebagian besar hewan juga memiliki tetapi jumlahnya tidak pasti berjumlah lima buah. Salah satu pembuluh darah ada di setiap jari yang mengalir ke ujung-ujung jari , sehinnga bisa menghasilkan frekuensi aliran darah yang 
berupa denyut nadi. Selain itu, jari juga sering digunakan sebagai alat komunikasi lewat gerak dan bentuk jari tersebut. Salah satu contoh yang sering digunakan oleh para penyandang tunawicara, mereka berkomunkasi memalui gerak-gerakan yang mengandung arti tertentu.

\subsection{Jantung}

Jantung dalam terminologi sederhana, merupakan sebuah pompa yang terbuat dari otot. Istilah kardiak berarti berhubungan dengan jantung, dari bahasa Yunani cardia untuk jantung. Jantung merupakan salah satu organ terpenting dalam tubuh manusia yang berperan dalam sistem peredaran darah yang berfungsi untuk memompa darah ke paru-paru dan ke seluruh bagian tubuh dan terletak di rongga dada di antara kedua paru-paru. (Nuryati, 2010). Anatomi jantung manusia terlihat pada gambar 2 .

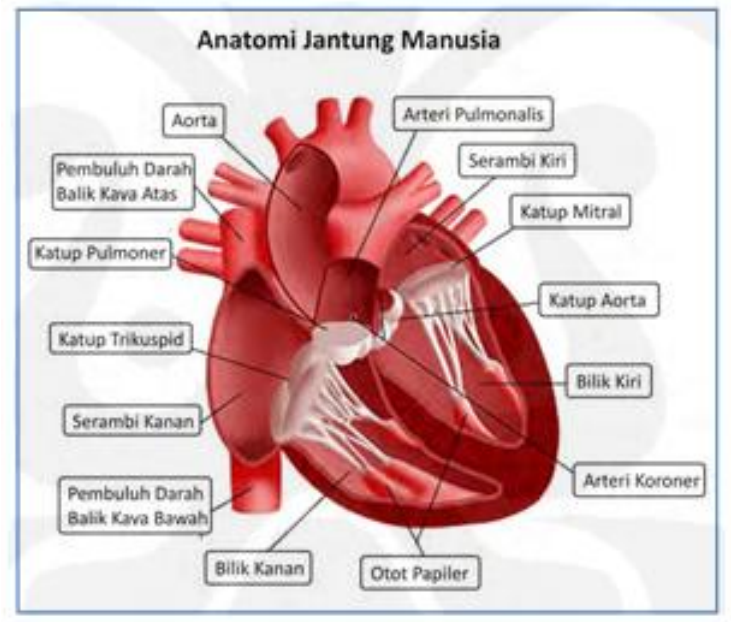

Gambar 2:Anatomi Jantung Manusia (Sumber : Cara Kerja Fungsi Anatomi

Fisiologi Jantung Manusia , 2010)

\subsection{Denyut Nadi}

Menurut Handayani (2014:5-6), Denyut nadi adalah suatu gelombang yang teraba pada arteri bila darah dipompa keluar jantung. Denyut ini mudah diraba disuatu tempat dimana arteri melintasi sebuah tulang yang terletak dekat permukaan. Seperti arteri radialis disebelah depan pergelangan tangan, arteri temporalis diatas tulang temporal, atau arteri dorsalis pedis dibelokan mata kaki.

Tabel 1: Kecepatan Normal Denyut Nadi Dipengaruhi Faktor Umur

\begin{tabular}{cc}
\hline Umur & BPM \\
\hline$<1$ Bulan & $90-170$ \\
$<1$ Tahun & $80-160$ \\
2 Tahun & $80-120$ \\
6 Tahun & $75-115$ \\
10 Tahun & $70-110$ \\
14 Tahun & $65-100$ \\
$>14$ Tahun & $60-100$ \\
\hline
\end{tabular}

\subsection{Stetoskop}

Stetoskop berasal dari bahasa Yunani yaitu stéthos yang berarti dada dan skopé yang berarti pemeriksaan. Stetoskop adalah sebuah alat medis akustik yang berfungsi untuk auskultasi, atau mendengarkan suara-suara internal tubuh, seperti suara jantung, paru, dan usus.

\subsection{Mikrokontroller}

Menurut Nuryati (2010:16)

Mikrokontroler adalah single chip computer yang memiliki kemampuan untuk diprogram dan digunakan untuk tugas-tugas yang berorientasi kontrol. Mikrokontroler datang dengan dua alasan utama, yang pertama adalah kebutuhan pasar (market needed) dan yang kedua adalah perkembangan teknologi baru. Yang dimaksud dengan kebutuhan pasar adalah kebutuhan yang luas dari produkproduk elektronik akan perangkat pintar sebagai pengontrol dan pemroses data. Sedangkan yang dimaksud dengan perkembangan teknologi baru adalah perkembangan teknologi semikonduktor yang memungkinkan pembuatan chip dengan kemampuan komputansi yang sangat cepat, bentuk yang semakin mungil, dan harga yang semakin murah.

\subsection{Arduino}

Menurut Schmidt (Dinata 2014:1), Arduino awalnya dibangun untuk desainer dan seniman-orang dengan keahlian teknis sedikit. Bahkan tanpa pengalaman 
pemrograman, Arduino memungkinkan mereka untuk membuat prototipe desain yang canggih dan beberapa karya seni interaktif yang menakjubkan.

\subsection{Arduino Uno}

Papan Arduino merupakan papan mikrokontroller yang berukuran kecil atau dapat diartikan juga dengan suatu rangkaian berukuran kecil yang didalamnya terdapat komputer berbentuk suatu chip yang kecil. Arduino didefinisikan sebagai sebuah platform elektronik yang open source, berbasis pada software dan hardware yang fleksibel dan mudah digunakan, yang ditujukan untuk seniman, desainer, hobbies dan setiap orang yang tertarik dalam membuat objek atau lingkungan yang interaktif. Arduino pada awalnya dikembangkan di Ivrea, Italia

\subsection{Sensor Detak Jantung (Sensor Max30100)}

Sensor ini dapat digunakan untuk mempermudah penggabungan antara pengukuran detak jantung dengan aplikasi data ke dalam pengembangannya. Sensor Max30100 mencakup sebuah aplikasi monitoring. Pada Sensor Max30100 digunakan LED berwarna merah, karena sensor cahaya yang digunakan yaitu APDS-9008 memiliki puncak sensitivitas sebesar $5.65 \mathrm{~mm}$. Dalam hal ini LED merah memiliki panjang gelombang 495$570 \mathrm{~nm}$ sehingga sesuai dengan kebutuhan sensor tersebut.

\subsection{Data Dictionary (Kamus Data)}

Menurut Raharjo (2015:48), dalam suatu rancangan database, data dictionary digunakan untuk menjelaskan atau mendeskripsikan kolom-kolom pada masing-masing tabel yang akan dibuat ke dalam database. Deskripsi kolom yang dimaksud di sini meliputi tipe data, lebar karakter atau digit, serta keterangan tentang kunci relasi.

\section{Metode Penelitian}

3.1 Spesifikasi Perangat yang dibutuhkan Spesifikasi perangkat yang dibutuhkan Pada penelitian ini digunakan perangkat keras (hardware) dan perangkat lunak (software) yaitu:

a. Perangkat keras (hardware)

Komponen yang digunakan untuk membangun alat pengukur detak jantung manusia adalah:

Tabel 2: Komponen Alat Pengukur Detak Jantung Manusia

\begin{tabular}{lc}
\hline \multicolumn{1}{c}{ Komponen } & JML \\
\hline Arduino Uno ATMega328 & 1 \\
Kabel USB & 1 \\
Pulse SensorAPDS-9008 & 1 \\
Personal Computer (PC) & 1 \\
Timah dan Pasta Solder & 1 \\
Jumper Cable female to male & 1 \\
Jumper Cable male to male & 1 \\
Box Plastik dan Perekat & 1 \\
Project Board (Simulasi) & 1 \\
\hline
\end{tabular}

b. Perangkat lunak (software)

Spesifikasi perangkat lunak yang digunakan untuk membangun sistem ini dibutuhkan perangkat lunak sebagai berikut:

1. windows 7

2. IDE Arduino (Arduino Development Environment)

3. Delphi 7

4. Xampp

\subsection{Metode Pengumpulan Data}

Metode yang dilakukan dengan cara sebagai berikut :

a. Melakukan observasi pada alat pengukur detak jantung (stetoskop) yang ada di rumah sakit atau laboratorium medis.

b. Melakukan konsultasi dan bimbingan dari dosen pembimbing serta sumbersumber lain yang dapat dijadikan sebagai acuan dan perbandingan dalam merancang alat ini.

c. Melakukan studi kepustakaan dengan cara mencari buku-buku dan 
mengumpulkan informasi yang berkaitan dengan perancangan alat ini.

d. Mengumpulkan data-data dan informasi yang diperlukkan dalam pembuatan alat ini dengan menggunakan fasilitas internet

\subsection{Desain Sistem Secara Umum}

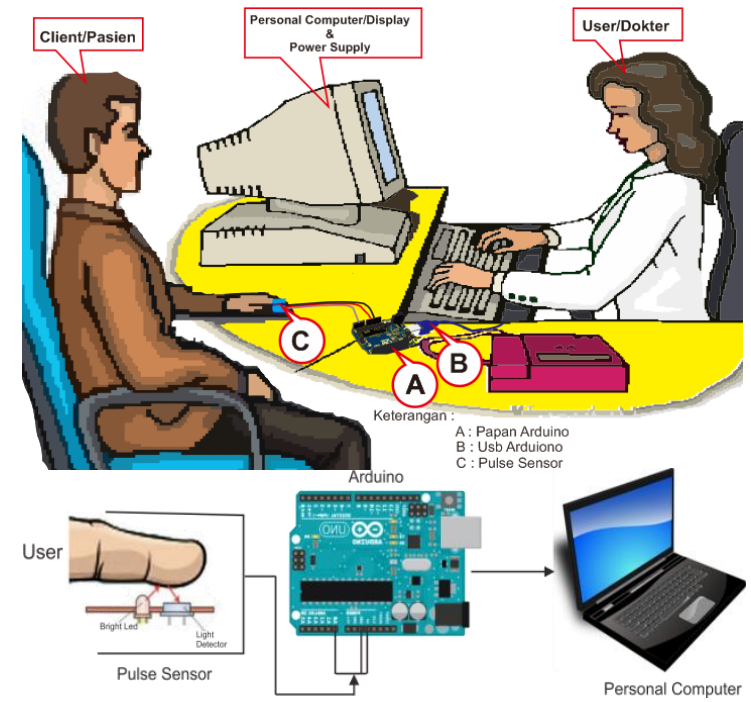

Gambar 3 Gambaran Umum Perancangan Sistem

Secara umum penelitian ini membahas tentang perancangan serta pembuatan sebuah alat untuk mengukur detak jantung manusia. Pada dasarnya perancangan ini terbagi menjadi dua yaitu perangkat keras (hardware) dan perangkat lunak (software). Perangkat keras pada perancangan ini terdiri dari pulse sensor yang berfungsi sebagai sumber data pengukuran dan arduino uno sebagai pemrosesan data yang berasal dari pulse sensor. Kemudian perangkat lunak yang terdapat pada pada personal computer yang berfungsi untuk menampilkan data hasil pengukuran dari arduino uno yang dikirim melalui kabel USB dan sebagai power supply untuk memberikan tegangan pada alat. Selain itu pada peragkat lunak juga dirancang untuk menyimpan data hasil pengukuran ke dalam database. Berikut gambaran umum sistem yang telah dirancang pada gambar 3.2 dibawah ini :

\subsection{Perancangan Hardware}

Perancangan hardware disajikan dengan menggunakan diagram blok yang dapat menguraikan hubungan yang berurutan dari suatu atau lebih komponen yang memiliki kesatuan kerja tersendiri dan setiap blok komponen mempengaruhi komponen yang lainnya.Adapun diagram blok dari sistem yang dirancang dapat dilihat pada gambar 3 .

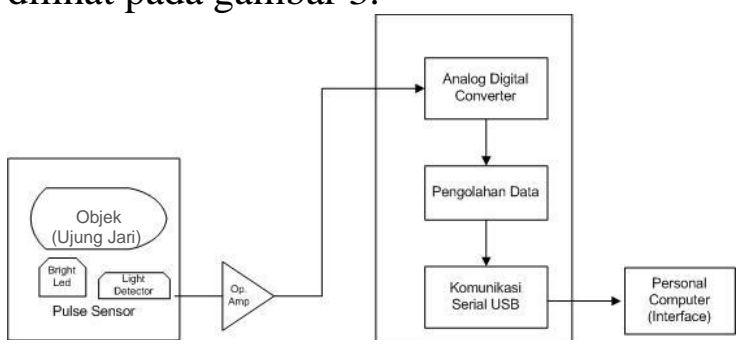

Gambar 3:Diagram Blok Perancangan

Sistem

Penjelasan fungsi tiap blok sistem :

a. Blok objek pada penelitian ini adalah satu jari tangan yang akan dmasukkan kedalam sensor. Pada sensor tersebutterdapat sebuahLED green yang akanmemancarkancahayauntukmenem busjaringan-jaringan yang adapadajaritangan. Pada sensor terdapatjugasebuahlight detector yangberfungsisebagaipenerimatembusa ncahaya.

b. Blok sensor yang terdapat bright led sebagai memberi cahaya dan light detector sebagai pendeteksi atau penerima cahaya.

c. Op-Amp berfungsi untuk menguatkan sinyal yang akan dikirim ke mikrokontroller. Sinyal ini adalah merupakan keluaran dari light detector.

d. Blok ADC (Analog Digital Converter) berfungsi sebagai pengubah data analog yang berasal dari photodioda untuk diubah kebentuk data digital.

e. Blok pengolahan data akan menerima sinyal dari Block ADC internal mikrokontroller berupa sinyal digital dan dilanjutkan ke pemprosesan data sesuai dengan 
program pada mikrokontroller.

f. Blok komunikasi serial/USB sebagai jalur komunikasi data serial antara mikrokontroller dengan PC untuk menampilkan hasil pengukuran oleh sistem alat.

g. Blok personal computer (PC) berfungsi menerima hasil pengukuran. Hasil pengukuran akan ditampilkan berupa angka dan diagram kemudian menyimpan hasil pengukuran ke dalam database.

\subsection{Flow Chart (diagram alir) Program}

a. Flowchart Program Pada Mikrokontroller

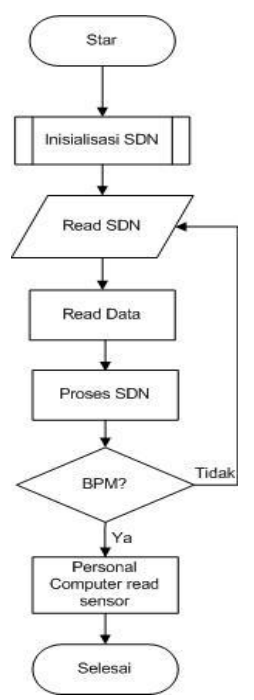

Gambar 4 Flowchart Program Pada Mikrokontroller

Pada saat program dimulai maka terjadi inisialisas sensor sebagai port input dan juga inisialisasi terhadap variabel BPM sebagai jumlah denyut sebagai pengambilan data sensor. Alur kerja dari sistem ini akan bekerja pada saat semua alat sudah dipasang dengan baik. Pada saat sensor dihubungkan dengan titik sumber detak jantung seperti jari tangan. Maka sensor mulai bekerja (menghitung jumlah denyut). Jika terdeteksi ada pulsa/denyut maka sistem secara otomati menampilkan hasil pengukuran dalam bentuk angka dan grafik pada personal computer.

b. Flowchart Program Pada Personal Computer (PC)

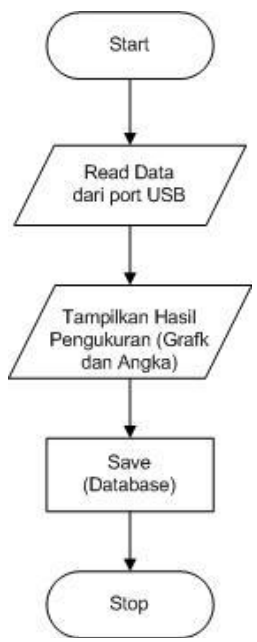

Gambar 5 Flowchart Program Pada Mikroontroller

Pada saat memulai program maka terjadi proses komunikasi dengan mikrokontroller dan membaca data nilai bpm dari mikrokonroller yang diterima melalui USB yang terhubung dengan mikrokontroller dan PC. Kemudian akan tampil hasil pengukuran berupa grafik dan angka setelah itu menyimpan data hasil pengukuran ke database.

\subsection{Perancangan Basis Data}

Adapun perancangan basis data dapat dilihat pada relasi antar tabel yang digunakan pada penelitian ini terlihat pada gambar 6 . Dalam database terdapat dua tabel yang saling berelasi yakni tabel biodata dan tabel pengukuran.

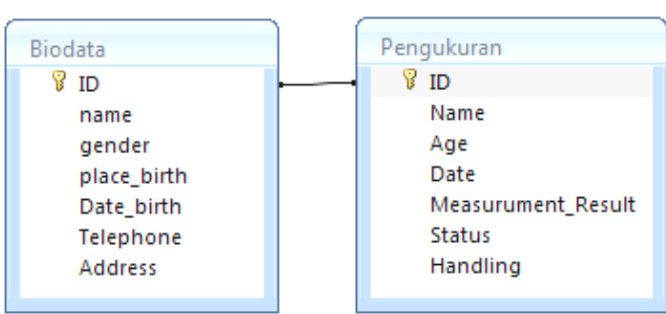

Gambar 6 Relasi Tabel Heart Rate 


\subsection{RancanganAplikasipada $P C$}

Pada perancangan aplikasi di $P C$, terdapat 6 bagian menu, yaitu : Menu main, Menu report pengukuran, Menu Biodata, Menu Biodata Report, Menu Description dan Menu Author.

a. Tampilan menu Main

Pada gambar 7 merupakan desain tampilan main pada aplikasi di $P C$.

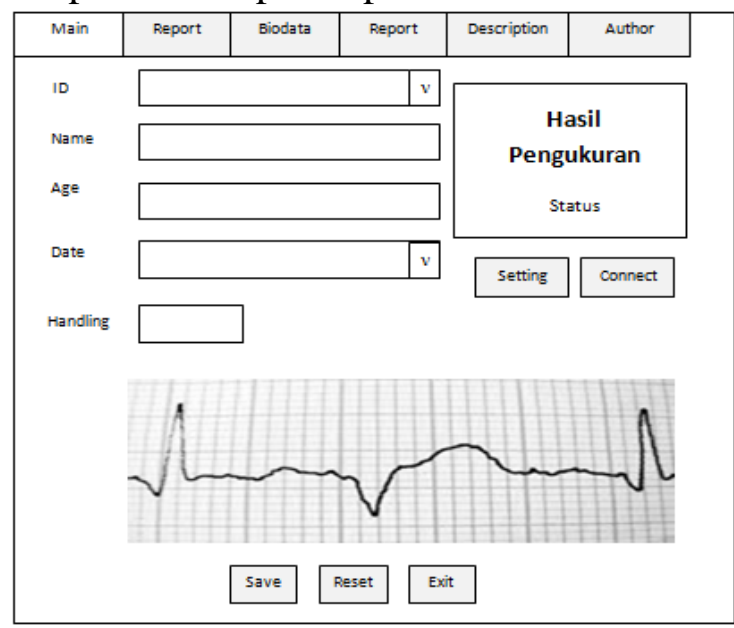

Gambar 7 Tampilan Main

Main berfungsi sebagai media untuk menampilkan data yang diterima dari mikrokontoller melalui kabel USB. Data yang telah diterima kemudian ditampilkan kedalam bentuk diagram dan angka. Di menu utama terdapat beberapa kolom yang digunakan untuk mengisi identitas diri, selain itu di menu utama juga terdapat 3 tombol (button) yang masing-masing memiliki fungsi, yaitu :

1) Tombol save berfungsi untuk menyimpan data hasil pengukuran diterima.

2) Tombol reset berfungsi untuk menghapus hasil pengukuran dan chart.

3) Tombol exit berfungsi untuk menutup atau keluar dari program.

4) Menu ReportPengukuran

Gambar 8 adalah tampilan menu report pengukuran pada aplikasi di PC:

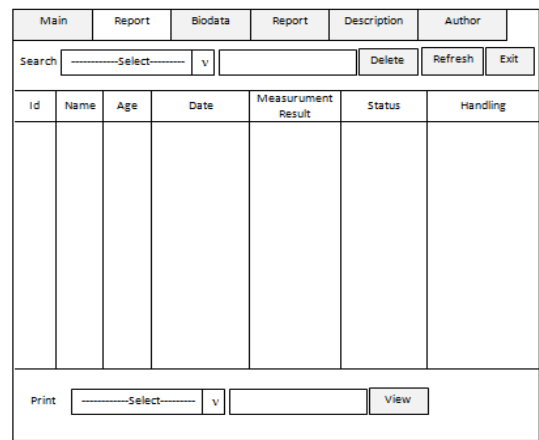

Gambar 8 Tampilan Menu Report

Pengukuran

Menu report ini berfungsi untuk menampilkan data hasil pengukuran laporan yang tersimpan di database. Selain itu, menu ini disiapkan menu pencarian yang digunakan untuk melakukan pencarian data berdasarkan id, name, dan status serta mencetak, menghapus perihal yang dicari.

b. Tamilan menuBiodata

Pada gambar 9 merupakan desain tampilan menu Biodata pada aplikasi di PC.

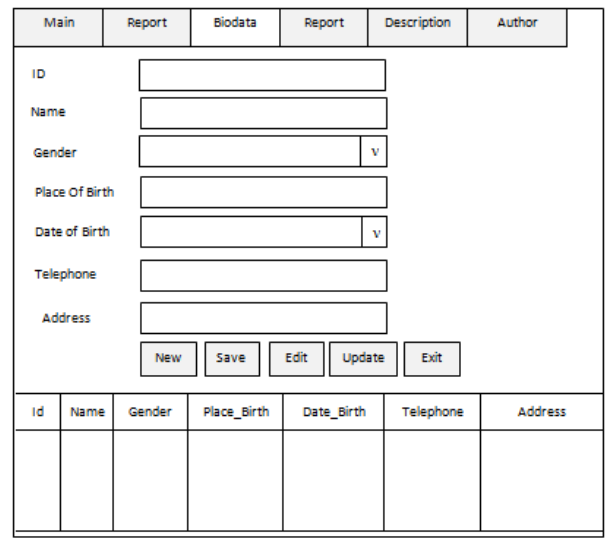

Gambar 9 Tampilan menu Biodata

Biodata berfungsi sebagai media untuk menginput mengubah data pasien.

1) Tombol New berfungsi untuk menambah data atau membuat data baru dan menampilkan otomatis id pasien yang di tambahkan

2) Tombol save berfungsi untuk menyimpan data hasil pengukuran diterima.

3) Tombol edit berfungsi untuk menampilkan data pada box setelah memilh data yang ingin di ubah pada tabel. 
4) Tombol update berfungsi untuk menyimpan data yang telah diubah.

5) Tombol exit berfungsi untuk menutup atau keluar dari program.

6) Tampilan Menu Report

Gambar10 adalahtampilan menu reportmenampilkan biodata pasisen yang telah diperiksa detak jantungnya.

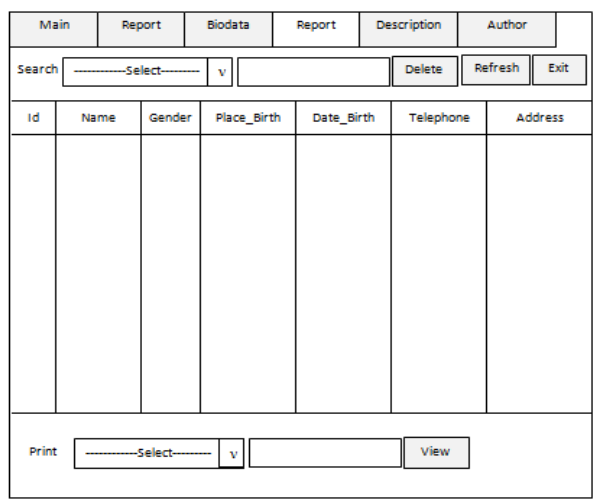

Gambar 10 Tampilan Menu Report Biodata

c. Menu Description

Berikut ini adalah gambar tampilan menu description

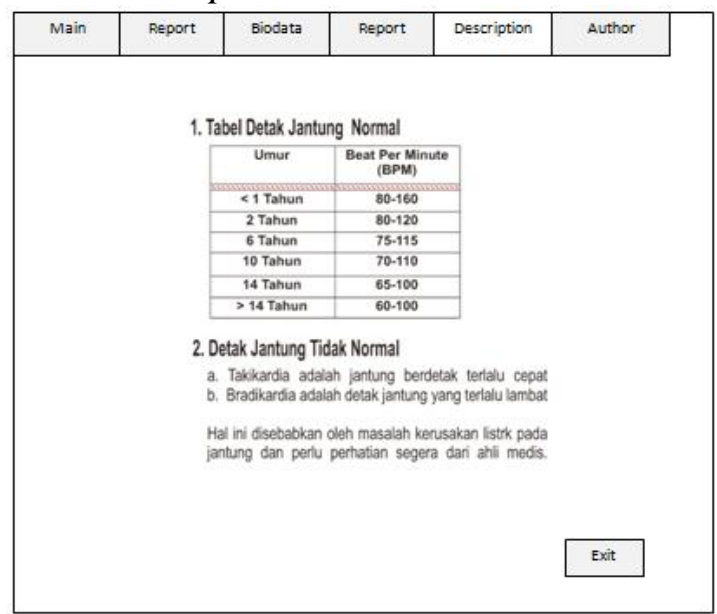

Gambar 11 Gambar Tampilan Menu Description

Menu Description berfungsi menampilkan penjelasan tentang detak jantung normal dan tidak normal.

d. Pengujian Alat

Pengujian alat dilakukakan pada obyek penelitian yaitu manusia. Alat ini akan mengukur detak jantung manusia. Paremeter yang diukur berupa sinyal denyut jantung per menit (BPM) manusia. Pengukuran denyut jantung menggunakan pulse sensor yang di tempelkan di ujung jari manusia. Hasil pengukuran tersebut akan ditampilkan di layar / monitor personal computer. Setelah itu, hasil pengukuran menggunakan alat akan dibandingkan dengan hasil menggunakan stetoskop yang biasa digunakan oleh para dokter untuk menentukan akuratnya alat yang dibuat.

\section{HasildanPembahasan}

\subsection{Hasil dan Pembahasan Perakitan}

Hardware

Perangkat keras yang berhasil dibuat dalam penelitian ini adalah alat pengukur detak jantung manusia berbasis arduino dengan tampilan personal computer yang berfungsi untuk mengukur detak jantung manus menggunakan arduino uno sebagai pemprosesan data pengukuran dan personal computer sebagai interface yang berfungsi sebagai media tampilan hasil pengukuran detak jantung manusia kemudian menyimpan hasil pengukuran ke dalam database.

Pada gambar 12 adalah hasil perakitan alat yang terhubung pada PC.

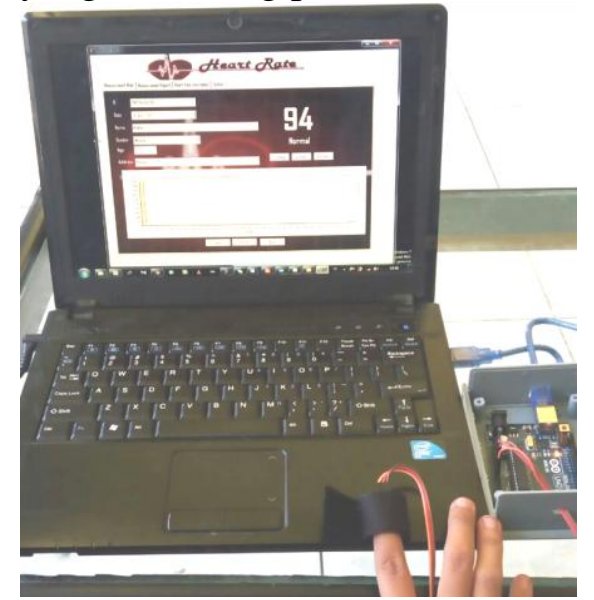

Gambar 12 Hasil Perancangan Hardware Yang terhubung ke PC

4.2 Hasil dan Pembahasan Perangkat Lunak (Software)

Sesuai rancangan pada gambar7 sampai gambar 11, maka tampilan hasil pembuatan software pada PC yang berfungsi untuk menampilkan data hasil pengukuran detak jantung manusia. Pembuatan software ini menggunakan 
bahasa pemograman Borlad Delphi 7 dan database yang dibuat menggunakan Xampp (MySQL) yang berfungsi untuk menyimpan data hasil pengukuran. Adapun hasil pembuatan perangkat lunak anatara lain:

a. Halaman Menu pengukuranberfungsi untuk menampilkan hasil pengukuran. Padahalamaninidilengkapi 5 tombol yang memilikifungsitersendiri sebagaimana dijelaskan pada tahap perancangan nomor 3.7 poin a.

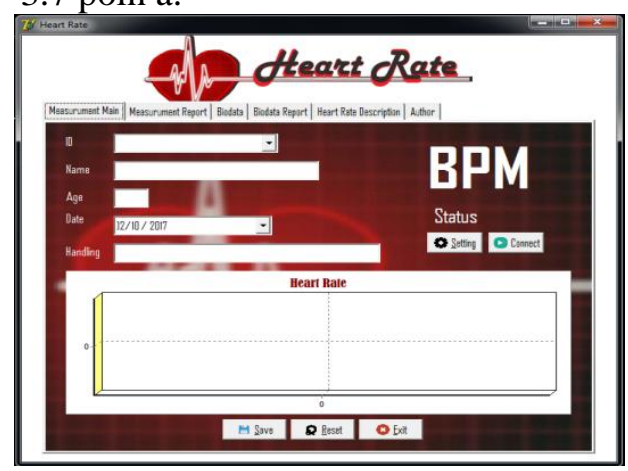

Gambar 13 Halaman Main

b. TampilanHalaman

Report pengukuranberfungsi untuk menampilkan data hasil pengukuran. Pada halaman ini 4 tombol yang memiliki fungsi tersendiri sebagaimana dijelaskan pada tahap perancangan nomor 3.7 poin $b$.

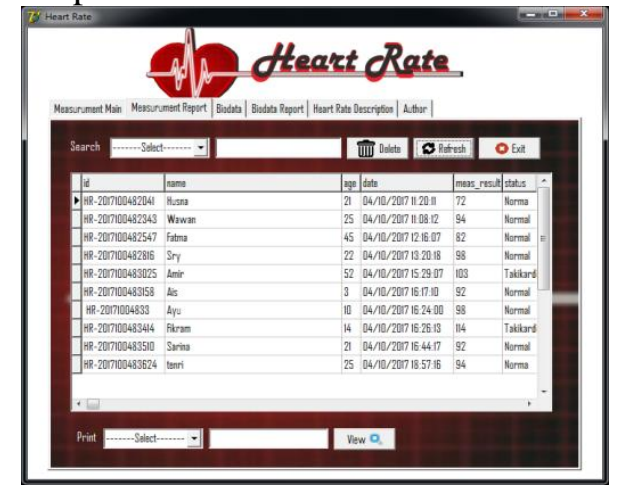

Gambar 14 Tampilan Report

c. HalamanBiodatapengukuran berfungsi untuk menginput data pasien. Padahalamanini 5 tombolyang memilikifungsitersendiri sebagaimana dijelaskan pada tahap perancangan nomor 3.7 poin $\mathrm{c}$.

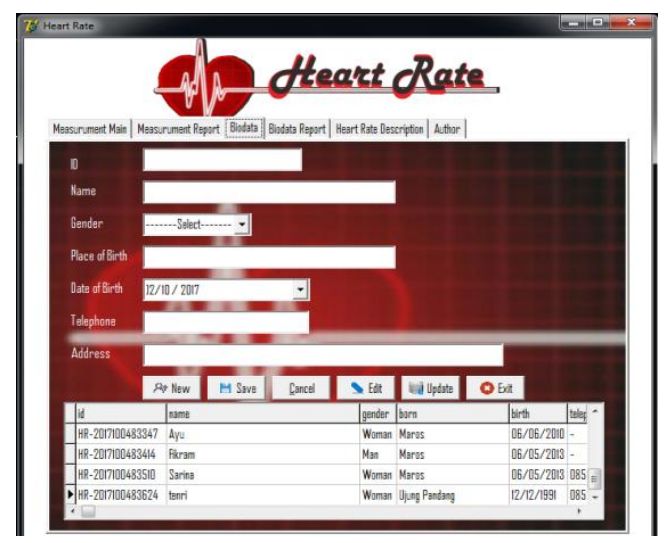

Gambar 14 Halaman Biodata

d. TampilanHalamanReport

Biodataberfungsi untuk menampilkan data pasien. Pada halaman ini 4 tombol yang memiliki fungsi tersendirisebagaimana dijelaskan pada tahap perancangan nomor 3.7 poin $\mathrm{d}$.

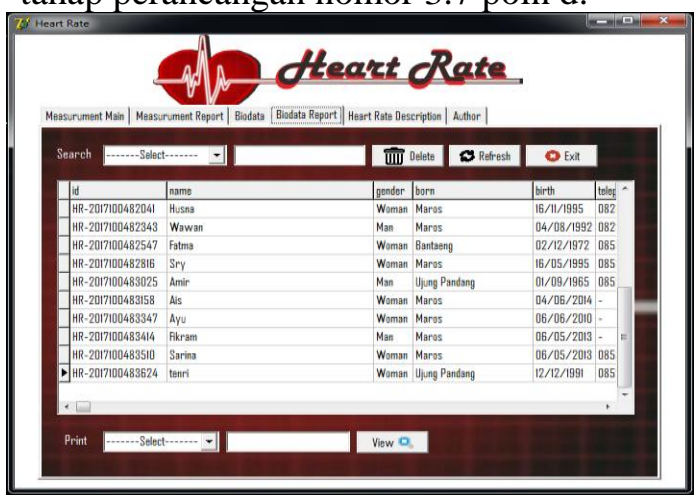

e. Tampilan Halaman Description berfungsi untuk menampilkan konten tentang detak jantung normal dan tidak normal.

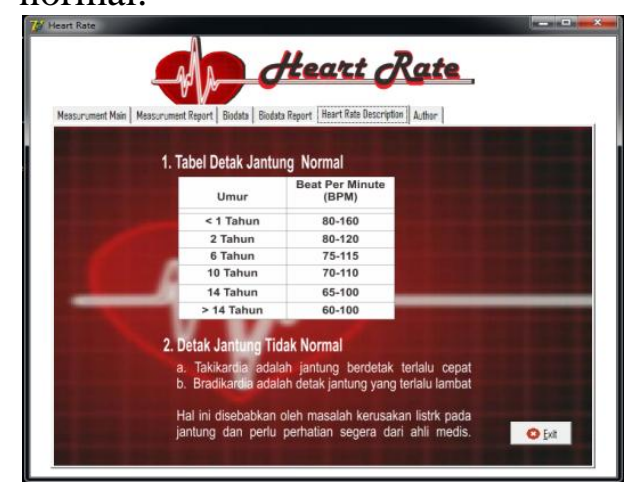

Gambar 15. Halaman Description

4.3 Hasil dan Pembahasan

Pengujian Pengujian ini dilakukan untuk menjalankan sistem secara keseluruhan. Pengujian dilakukan dengan menjalankan program (software) dan alat 
(hardware) yang telah dibuat. Pengujian dilakukan dengan mengambil 10 sample data dari 10 orang yang berbeda. Data yang didapat dari pengukuran menggunakan sistem secara keseluruhan dapat dibandingkan dengan perhitungan manual (stetoskp) sehingga dapat dihitung presentase error. Perhitungan presentase error dapat dilihat dari rumus berikut :

$$
\% \text { Error }=\frac{\Delta \mid \text { Alat }- \text { Stetoskop } \mid}{\text { stetoskop }} \times 100
$$

Sehingga untuk mendapatkan akurasi sistem dalam \% maka rumusnya: Akurasi $=(100-$ Error $) \%$

Tabel 1 Tabel Pengamatan

\begin{tabular}{llllll}
\hline No. & Nama & $\begin{array}{c}\text { Usia/J } \\
\text { K }\end{array}$ & $\begin{array}{c}\text { Hasil Ukur } \\
\text { Alat }\end{array}$ & $\begin{array}{c}\text { Stetes } \\
\text { kop }\end{array}$ & $\begin{array}{c}\text { Akurasi } \\
\text { \% }\end{array}$ \\
\hline 1. & Husna & 21/P & 72 & 76 & 5,74 \\
2. & Wawan & 25/L & 94 & 90 & 95,56 \\
3. & Sry & 22/P & 98 & 90 & 93,48 \\
4. & Fatma & 45/P & 82 & 72 & 86,11 \\
5. & Amir & 52/L & 103 & 96 & 92,71 \\
6. & Ais & 3/P & 92 & 86 & 93,02 \\
7. & Ayu & 10/P & 98 & 93 & 94,62 \\
8. & Fikram & 14/L & 114 & 100 & 86 \\
9. & Sarina & 21/P & 92 & 88 & 95,45 \\
10. & Tenri & 25/P & 94 & 87 & 91,95 \\
Rata-Rata Akurasi & & & $\mathbf{9 2 , 3 6}$ \\
\hline \multicolumn{5}{l}{}
\end{tabular}

Dari 10 orang yang dilakukan pengujian terbukti akurasi alat adalah 92,36\%.

\section{Kesimpulan}

Dari penelitian yang telah dilakukan, maka dapat disimpulkan bahwa

a. Hasilpengukurandetakjantung dapat dilihat pada personal computerdanmenyimpan data tersebutpada database sehinggadapatdibukakembalidanmemband ingkanhasilpengukuransetelahmelakukanp engukuran.

b. Alat yang digunakanuntuk mengukur detak jantungmanusiaadalal pulse sensor sebagaisumberpengukurandanarduinos ebagaipemrosesan data yang berasaldari pulse sensor. HasilPengujiandengantingkatakurasi 92,36 sehinggakemungkinanbesaralatinilayak digunakan.

\section{Daftar Pustaka}

[1] Dinata, Yuwono Marta. 2014. Arduino Itu Mudah. Jakarta: PT. Elex Media Komputindo.

[2] Djuandi, Feri. 2011. Pengenalan Arduino. Tersedia: http://tobuku.co $\mathrm{m} /$ docs/Arduino-Pengenalan.pdf. Diakses pada tanggal 13 Juni 2017.

[3] Handayani, Eka Sri. 2014. Rancang Bangun Alat Pengukur Denyut Nadi Melalui Pendeteksian Jari Tangan Berbasis Mikrokontroler ATMega 8535. Politeknik Sriwijaya, Sumatera Selatan. Tersedia http://eprints.polsri.ac.id/1399/3/B $\mathrm{AB} \%$ 20II.pdf. Diakses pada tanggal 22 Desember 2016.

[4] Iqfadhilah, 2015. Pengertian dan Fungsi Stetoskop dan Sejarah Penemuan Stetoskop. Tersedia : http://www.idmedis.com/20 15/12/pengertian-dan-fungsistetoskop-dan.html. Diakses pada 13 Juni 2017

[5] Iskandar Akbar, Lisah. 2017.Sistem Keamanan Pintu Berbasis Arduino Mega.Jurnal Informatika Upgris Vol.5 No.2.

[6] Masmuksti. 2011. Pengantar Engineering Design. Tersedia: http://masmukti.files.wordprees.co m. Diunduh pada tanggal 13 Juni 2017

[7] Nuryati, Venti. 2010. Rancang Bangun Alat Pendeteksi dan Penghitung Detak Jantung dengan Asas Doppler. Universitas Indonesia, Depok.

[8] Raharjo, Budi. 2015. Belajar Otodidak MySQL (Teknik Pembuatan dan Pengelolaan Database). Penerbit: Informatika Bandung. 
[9] Santoso, Hari. 2015. Arduino Untuk Pemula V1. Tersedia: http://www .elangsakti.com/2015/07/ebookgratis-belajar-arduinopemul .html. Diakses pada tanggal 12 Juni 2017. [10]Sibagariang, Ketty Winata. 2016. Perancangan Sistem Pengukur Detak Jantung Secara Jarak Jauh Berbasis Atmega 8535 Dengan Tampilan PC. Tersedia: http://repository.usu.ac.id/bit stream/handle/123456789/63110/C hapter\%20II.pdf?sequen=4\&isAllo wed $=y$. Universitas Sumatera Utara, Medan.

[11] Suciati dan Rahmadsyah, A. 2016. Berdasarkan Data WHO Penyakit Kardiovaskular Penyebab Kematian Nomor Satu. Tersedia : http://m.jitunews.com $/ \mathrm{read} / 35580 / \mathrm{b}$ erdasarkan-data-who-pen yakitkardiovaskular-penyebabkematian-nomor-satu. Diakses pada tanggal 12 Juni 2017.

[12]UPT - Balai Informasi Teknologi Lipi, 2009. Pangan dan Kesehatan, Bandung. Penerbit: Lembaga Informasi Pengetahuan Indonesia.

[13] Wahana Komputer. 2013. Panduan Aplikatif dan Solusi (Aplikasi Cerdas Menggunakan Delphi), Semarang. Penerbit: Andi Offset.

[14] Witriza, Yulni. 2017. Pengontrolan Alat Listrik Secara Otomatisasi Menggunakan Sensor Cahaya dan Sensor Suhu BerbasisMikrokontroler.

Universitas Sumatera Utara, Medan. 